Profit: Jurnal Kajian Ekonomi dan Perbankan 2 (2) 2018. P: $52-72$

PROFIT : JURNAL KAJIAN EKONOMI DAN PERBANKAN https://ejournal.unuja.ac.id/index.php/profit

E-ISSN : 2597-9434, ISSN: 26854309

\title{
IMPLIKASI FORCE MAJEURE PADA AKAD PERSPEKTIF USHUL FIQH DAN FIQH (STUDI PADA AKAD SALAM)
}

Moh Syaiful Suib*

- Fakultas Agama Islam Universitas Nurul Jadid

\begin{abstract}
:
Penelitian ini bertujuan untuk mendeskripsikan implikasi force majeure pada akad perpektif figh dan ushul fiqh,yang dalam akad dilakukan oleh beberapa pihak dengan transaksi menggunakan akad salam. Penelitian ini juga dengan memberikan gambaran terhadap model transaksi dua akad salam. Hasil penelitian ini menunjukkan bahwaKetentuan hukum dalam akad-akad baik salam ataupun lainnya, akan berubah secara totalitas ketika berkaitan dengan force majeure, yaitu keadaan memaksa. Dampak dari force majeure ini adalah ketidakadanya kepastian hukum yang terjadi pada waktu terjadinya force majeure tersebut. Ketentuan hukum ini
\end{abstract} akan berlaku lagi ketika keadaan sudah aman dan terkendali.

Keyword:
Email :syaifulsuib@gmail.com 


\section{PENDAHULUAN}

Islam agama bersifat universal, mengatur semua prilaku kehidupan manusia baik berhubungan kepeda Allah dalam bentuk ibadah maupun berhubungan dengan manusia yang berhubungan dalam bentuk muamalah, begitu juga berhubungan dengan alam ini. Dari fitrohnya manuisia hubungan dalam bermuamalah akan berdampak kepada terpenuhinya kebutuhan dari berbagai macam segi, diantaranya ekonomi. ${ }^{1}$

Salah satu bentuk muamalah adalah salam dengan model jual beli dengan cara salam, yaitu akad pemesanan suatu barang dengan kriteria konsensus serta model pembayaran cas pada saat akad dilaksanakan. Implikasi dengan memakai akad ini kedua belah pihak mendapatkan keuntungan sesuai konsensus tersebut, tanpa adanya force majure dari kedua belah pihak.

Proses transaksi yang dilakukan dari pihak pembeli, (biasanya) diuntungkan berupa jaminan untuk mendapatkan produk/barang yang ia butuhkan dengan durasi waktu tertentu, begitu juga sebaliknya pihak penjual mendapatkan pesanan barang sebelum barang itu dibeli orang lain dan penjual dapat memproduksi lebih banyak barang serta dapat memprediksi yang ia inginkan para pembeli setelahnya.

Dari pengertian tersebut dapat diambil penjelasan bahwa akad salam akan membantu bagi orang yang tidak mempunyai uang yang di posisikan sebagai pembeli, dan bagi penjual ia juga mendapatkan porfit yang besar dengan banyaknya barang yang laku. Disamping itu juga penjual mendapatkan modal untuk menjalankan usahanya, sehingga ia dapat menjalankan dan mengembangkan usahanya tanpa harus membayar bunga. Dengan demikian selama belum jatuh tempo, penjual dapat menggunakan uang pembayaran tersebut untuk menjalankan usahanya dan mencari keuntungan sebanyak-banyaknya tanpa ada kewajiban apapun.Penjual memiliki keleluasaan dalam memenuhi permintaan pembeli, karena biasanya tenggang waktu antara transaksi dan penyerahan barang pesanan berjarak cukup lama. ${ }^{2}$

Namun demikian, yang menjadi permasalahan apabila setelah penyerahan barang kepada si pembeli tidak sesuai dengan spesifikasi yang telah ditentukan dalam perjanjian, misal adanya cacat pada barang. Masalah tersebut akan berdampak signifikan ketika dikaitkan dengan wilayah (zona) bagi si penjual yang hanya membutuhkan biaya/ongkos pengiriman lebih besar dari sebelumnya. Hal ini juga ketika dikaitkan semisal diluar wilayah/batas negara

\footnotetext{
${ }^{1}$ Al-Hujurat ; 12

${ }^{2}$ Ismail Nawawi, Fiqh Muamalah Klasik dan Kontemporer, 125 
yang memerlukan tambahan biaya yang cukup mahal, atau juga apabila terjadi force majure (sesuatu yang tidak dikehendaki) seperti bencana alam dan hal-hal lain.

Dari permasalahan ini, penulis mencoba untuk mengungkap dari sisi maqosidus syariah dan tinjauan dalam fiqh tentang keabsahan dalam transaksi tersebut serta dalil-dalil yang bersifat qoth'iy. Tinjauan dalam hukum Islam akan dipergunakan rujukan kitab-kitab fiqh yang empat seperti Ibnu Ruysd, dan lain sebagainya serta tinjauan dariMaqosidus syariah merujuk pada Kitab Maqosid seperti ar-Raysuni, dan lain-lain.

\section{TEORI}

Salam menurut ulama salaf, secara bahasa berarti pemesanan atau jual beli dengan melakukan pesanan terlebih dahulu. Akad Salam merupakan akad dimana pembeli memesan barang kepada si penjual dengan memberitahukan seluruh sifat-sifat dan kualitas barang kepada penjual dan terjadi kesepakatan diantara keduanya. Dengan kata lain , akad salam merupakan pembelian barang dengan membayar uang lebih dahulu kepada penjual dan barang yang di beli diserahkan kemudian (DowPayment) setelah terjadi kesepakatan diantara kedua pihak. Salam juga disebut jasa pre-paid purchase of goods, artinya pembayaran diberikan sebelum ada barangnya. ${ }^{3}$

Seperti kata penjual: "saya jual kepadamu kursi dengan model begini dengan harga Rp. 5.000.000,.setelah transaksi disetujui, pembeli membayarnya waktu itu juga walaupun kursinya belum ada. Jadi salam ini jual beli utang dari pihak penjual dengan kontan dari pihak pembeli, karena uangnya sudah dibayar sewaktu akad atau dengan perkataan lain: salam adalah jual beli berupa pesanan (in front payment sale) bisa disebut juga dow payment, artinya penyetoran sebagian harga pembelian sebagai bukti telah terjadi transaksi, maka diperlukan bukti pembayaran yang sah berupa kwitansi atau catatan yang ditandatanagani penerima uang.

\section{Landasan Syari'ah}

Landasan syari'ah transaksi ba'i as-salam terdapat dalam Al-Qur'an dan Al-Hadits.

\section{a. Al-Qur'an}

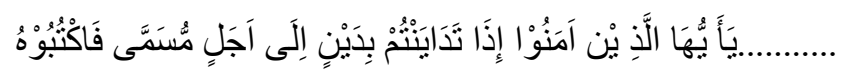

${ }^{3}$ Prof DR Sutan Remy Sjahdeini, SH, Perbankan Syariah, Produk-Produk dan Aspek-Aspek Hukumnya, Kencana, Jakarta, 2015), 251 
"Hai orang-orang yang beriman, apabila kamu bermuamalab tidak secara tunai untuk waktu yang ditentukan, hendaklah kamu menuliskannya... (QS. Al-Baqarah:282).

\section{b. Al-Hadits}

Ibnu Abbas meriwayatkan bahwa Rassulullaah Saw. Datang ke madinah dimana penduduknya melakukan salaf (salam) dalam buah-buahan (untuk jangka waktu) satu, dua, dan tiga tahun. Beliau berkata: ${ }^{5}$

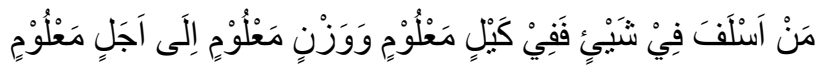

"Barang siapa yang melakukan salaf (salam), hendaknya ia melakukan dengan takaran dan timbangan yang jelas, untuk jangka waktu yang diketahui/ disepakati."

\section{Rukun dan Syarat Salam}

Rukun salam sebagai berikut: ${ }^{6}$ Muslam (pembeli), Muslamilaib ( penjual), Modal atau uang, Muslamfiibi(barang), Shigat (ucapan).Disamping segenap rukun salam, ada juga syaratsyarat yang harus dipenuhi yaitu modal dan barang. Pertama ; Modal dalam bentuk uang, harus diketahui berapa yang diberikan kepada penjual, kedua Barang yang menjadi pesanan harus diketahui kualitas, jenis serta jumlahnya pesanan.

2. Penerimaan pembayaran salam ${ }^{8}$

Kebanyakan ulama mengharuskan pembayaran salam dilakukan di tempat kontrak.

b. Al-Muslam Fiihi (Barang)

Diantara syarat-syarat yang harus terpenuhi dalam al-muslam fiibi sebagai berikut:

1. Harus spesifik dan dapat diakui sebagai utang

2. Harus bisa diidentifikasikan secara jelas untuk mengurangi kesalahan akibat kurangnya pengetahuan tentang macam barang tersebut.

3. Penyerahan barang dilakukan di kemudian hari

4. Kebanyakan ulama masyarakat penyerahan barang harus ditunda suatu waktu kemudian, tetapi mazhab syafi'i membolehkan penyerahan segera.

5. Bolehnya menentukan tanggal waktu di masa yang akan datang untuk penyerahan barang.

\footnotetext{
${ }^{4}$ QS. Al-Baqarah:282

${ }^{5}$ Ismail Nawawi, Fiqih Muamalah Klasik dan Kontemporer, 125

${ }^{6}$ Ibid, 126

${ }^{7}$ Ibid,

${ }^{8}$ Ibid,
} 
6. Tempat penyerahan. Pihak-pihak yang berkontrak harus menunjuk tempat yang disepakati dimana barang harus diserahkan.

D. Jenis Akad Salam

Ada dua jenis dari akad salam :

1. Salam biasa

Salam biasa adalah transaksi atau akad jual beli dimana barang yang diperjualbelikan belum ada ketika transaksi dilakukan, dan pembeli melakukan pembayaran dimuka sedangkan penyerahan barang baru dilakukan di kemudian hari dan ini yang terjadi pada skala kecil, biasanya transkasi penjualan dalam masyarakat, pasar tradisional, atau di medsos serta lainnya. Jadi dalam transaksi salam ini hanya terjadi diantara dua orang yaitu si penjual dan si pembeli. Berbeda dengan salam paralel yang melibatkan pihak ketiga sebagai penyedia barang.(supplier). ${ }^{9}$

2. Salam paralel ${ }^{10}$

Salam paralel adalah akad salam yang dilakukan dua transaksi salam yaitu antara pemesanan pembeli dan penjual serta antara penjual dengan pemasok (supplier) atau pihak ketiga lainnya (seperti yang terjadi di dalam perbankan. pelaksanakan transaksi Salam paralel ini dilakukan antara bank dan nasabah dan antara bank dan suplier atau pihak ketiga lainnya secara simultan. Hal ini terjadi ketika penjual tidak memilikibarang pesanan dan si penjual memesan kepada pihak lain untuk menyediakan barang pesanan tersebut. Salam ini biasanya diterapkan atau digunakan pada pembiayaan bagi barang industri dengan jangka waktu relatif pendek dan bank tidak ada niat untuk menjadikan barang-barang tersebut sebagai inventory (simpanan), yakni persediaan atau barang jadi suatu perusahaan.

Oleh karena itu, dilakukanlah akad Salam kepada pembeli kedua (distributor) misalnya kepada seperti pasar induk, pasar grosir, dan lain-lain.

Modus operandi akad salam paralel yang dilakukan oleh bank syariah ( ashraf usmani, t.th.: 50; DSN-MUI No .05/DSNMUI/IV/2000) ; bank membeli barang dari pemasok, barang nantinya dijual ke pembeli/nasabah yang memesan. 2. Dalam paralel salam ada dua perjanjian jual beli, pertama perjanjian antara pihak bank dengan pemasok (penjual), yang kedua ; perjanjian jual beli antra bank sebagai penjual, nasabah sebagai pembeli. Meskipun

9(Sutan Remy, Perbankan Syariah, 252), lihat...Veithzal Rivai, IslamicFinancialManagement, 2008, Jakarta, Rajagrafindo Persada, 173

${ }^{10} \mathrm{Ibid}, 173$ 
ada dua perjanjian, akan tetapi beda dua perjanjian tersebut berbeda secara hukum.implikasi dari keduanya adalah jika salah satu perjanjian gagal, maka tidak mempengaruhi kepada perjanjian yang satunya.ketiga, kualitas barang yang berikan tidak mempenaruhi terhadap perjanjian, apabila kualitas barang kurang baik. Dengan tidak meminta diskoun/pengurangan biaya, begitu juga sebaliknya, jika barang diserahkan lebih awal oleh si pemasok, juga tidak boleh meminta discoun terhadap barang tersebut. ${ }^{11}$

Syarat bai salam paralel;

UU No 21 Tahun 2008, Perbankan Syariah, akad salam (termasuk paralel salam), harus sesuai prinsip syariah. Fatwa DSN DSN-MUI No .05/DSNMUI/IV/2000) tentang jual beli salam memberikan ketentuansbb ;

Pertama; ketentuan tentang pembayaran;

1. Alat bayar harus di ketahui jumlah dan bentuknya, baik berupa uang, barang atau manfaat

2. Pembayaran dibayar saat kontrak di sepakati

3. Pembayaran tidak dalam bentuk pembebasan utang

Kedua ; ketentuan tentang barang

1. Harus jelas ciri-cirinya dan dapat diakui sebagai utang

2. Spesisifikasinya jelas

3. Penyerahan dilakukan setelahnya

4. Waktu penyerahan, sesuai kesepakatan

5. Pembeli tidak boleh mnejual barang sebelum menerimanya.

6. Tidak boleh menukar barang, kecuali sejenis, akan tetapi sesuai dengan kesepakatan.

Ketiga ; dibolehkan melakukan paralel salam dengan syarat, akad kedua tidak ada kaitan dengan akad pertama.

Keempat ; penyerahan barang sebelum waktunya

1. Peyerahan barang sesuai waktu yang ditentukan

2. Jika penjual menyerahkan kualitas tinggi, penjual tidak boleh meminta tambahan

3. Jiak penjual menyerahkan barang kualitas rendah, pembeli menerima, maka tidak boleh meminta discount.

4. Penjual dibolehkan menyerahkan barang lebih cepat dari waktu kesepakatan

${ }^{11}$ Ibid, 252 
5. Jika sampai batas kesepakatan barang belum ada, barang kualitas rendah, pembeli tidak rela menerimamnya, maka ia mempunyai dua opsi ; a. Membatalkan kontrak, dan meminta uangya kembali atau b. Menunggu barangnya tersedia.

Kelima ; pembatalan kontrak salam boleh, selama tidak merugikan kedua belah pihak

Keenam ; perselisihan. Jika terjadi perselisihan, maka diselesaikan melalui Badan Arbitrase Syariah setelah tidak tercapai dalam musyawarah.

Beberapa contoh Penerapan Salam Paralel dapat dijelaskan sebagai berikut : Adapun aplikasikan penerapan pada pembiayaan barang industri, misalnya pemesanan barang, spesifikasi barang diketahui umum. Nasabah/orang memesan barang kepada pabrik, pabrik mengajukan permohonan pembiayaan untuk pembuatan barang, bank mereferensikan penggunaan produk tersebut.Hal ini berarti bank memesan pembuatan barang dan membayarnya pada waktu pengikatan kontrak.Bank kemudian mengatarkan barang kepada nasabah/orang yang memesan. ${ }^{12} \mathrm{Akad}$ ini akan terjadi saling tolong menolong diantara penjual (pabrik) dan pembeli (custumer/nasabah) khususnya pengusaha yang kecil. Mereka tetap berproduksi dan menjaga mutu barang hasil industrinya dari hasil akad ini dan akan terwujud dalam siklus perdagangan ekonomi yang berkesinambungan.

\section{A. Force Majeure}

Force Majeure / keadaan memaksa (bahasa Perancis Force Majeure artinya kekuatan yang lebih besar ), sedangkan bahasa Belanda disebut overmacht, adalah suatu peristiwa/kejadian di luar kemampuan manusia dan tidak dapat dihindarkan sehingga suatu kegiatan tidak dapat dilaksanakan sebagaimana mestinya. Menurut Prof. Dr. R. Wirjono Prodjodikoro S.H. keadaan memaksa dalam hukum adalah keadaan yang menyebabkan bahwa suatu hak atau suatu kewajiban dalam suatu perhubungan hukum tidak dapat dilaksanakan. ${ }^{13}$

Di dalam KUH Perdata hanya dua pasal yang mengatur tentang Force Majeure, yaitu pasal 1244 dan pasal 1245 KUH Perdata. Di dalam pasal tersebut hanya mengatur masalah Force Majeure dalam hubungan dengan pergantian ganti kerugian dan bunga

\footnotetext{
${ }^{12}$ Ibid, 252

${ }^{13}$ Daryl John Rasuh, Kajian Hukum Keadaan Memaksa, (Force Majeure) menurut Pasal 1244 dan Pasal 1245 KUHPerdata, Jurnal Lex Privatum Vol 4 No 2 Februari 2016, 
saja, akan tetapi perumusan pasal - pasal ini dapat digunakan sebagai pedoman dalam mengartikan Force Majeure. Adapun dasar pikiran pembuat Undang - Undang ialah “ Suatu keadaan memaksa ( Force Majeure / Overmacth) adalah suatu alasan untuk dibebaskan dari kewajiban membayar ganti rugi. ${ }^{14}$.

Pasal 1244 KUH Perdata menyebutkan bahwa ;" Dalam hal ini, kejadian-kejadian yang merupakan force majeure tersebut tidak pernah terduga oleh para pihak sebelumnya. Sebab, jika para pibak sudah dapat menduga sebelumnya akan adanya peristiwa tersebut maka seyogyanya hal tersebut harus sudah dinegosiasi di antara para pibak."Beberapa pasal dalam KUH Perdata yang digunakan sebagai pedoman pada ketentuan dari forcemajeure di atas pada Pasal 1245 yang menjelaskan:"Tidaklah biaya rugi dan bunga, harus digantinya, apabila lantaran keadaan memaksa atau lantaran suatu kejadian tidak disengaja si berbutang berbalangan memberikan atau berbuat sesuatu yang diwajibkan, atau lantaran hal-bal yang sama telab melakukan perbuatan yang terlarang”. Pada pasal yang lain yaitu Pasal 1545 sebagai kelanjutan dari pasal 1245 menjelaskan:"Jika suatu barang tertentu, yang telah dijanjikan untuk ditukar, musnah di luar salah pemiliknya, maka persetujuan dianggap sebagai gugur, dan siapa yang dari pihaknya telah memenubi persetujuan, dapat menuntut kembali barang yang ia telah berikan dalam tukar-menukar". Begitu juga pada Pasal 1553 :"Jika selama waktu sewa, barang yang disewakan sama sekali musnah karena suatu kejadian yang tidak disengaja, maka persetujuan sewa gugur demi bukum". ${ }^{15}$

Dari rumusan pasal-pasal tersebut, setidaknya terdapat 3 (tiga) unsur yang harus dipenuhi untuk force majeure ini, yaitu :

1. Tidak memenuhi prestasi

2. Ada sebab yang terletak di luar kesalahan yang bersangkutan;

3. Faktor penyebab itu tidak diduga sebelumnya dan tidak dapat dipertanggungjawabkan kepada yang bersangkutan.

Dari beberapa hal di atas menunjukan bahwa force majeure timbul karena ada hal yang tidak terduga sebelumnya, akan tetapi apabila dapat diduga sebelumnya akan terjadinya sesuatu maka bukan termasuk force majeure. Contoh ketika pesawat yang melintasi rute suatu daerah dan sudah dipastikan oleh BMKG adanya badai di udara, pesawat tersebut sudah mengetahui bahaya tersebut, kemudian tetap melewati daerah tersebut dan berspekulasi akan selamat melewati daerah tersebut, maka tidak termasuk

\footnotetext{
${ }^{14}$ R.Subekti, Hukum Perjanjian, Jakarta, PT.Intermassa, 1979,55

${ }^{15}$ Ibid, 55
} 
force majeure. Karena hal itu sudah diduga mengetahui peristiwa dan resiko yang akan dihadapi pesawat tersebut.

Dalam Islam istilah forcemajeure disebut juga dengan keadaan dharurat.Dalam kaidah fiqh dijelaskan bahwa ada beberapa penerapan dalam kaidah dhorurot membolehkan hal-hal yang bersifat dhorurat membolehkan sesuatu yang perbuatan dilarang boleh dilakukan. Kaidah ini berbunyi الضرورة تببح المحظورات; (hal-hal yang dibolehkan dalam kondisi dhorurat, pemenuhannya harus sesuai kadar situasi dharurat yang menyebabkannya). Larangan dalam nas menyebabkan dibolehkannya sesuatu yang tidak boleh dilakukan menjadi boleh dilakukan dengan menggunakan kaidah ini. ${ }^{16}$

Menurut Imam Syaikh as-Sa'adi dalam syairnya mengatakan;

\section{و لا حرم مع ا ضطرار}

Artinya ; tidak ada keharaman beserta adanya kemudharatan.

Sumber kaidah ini berasal dari firman Allah, dalam surat al-Baqoroh ayat 173 ;

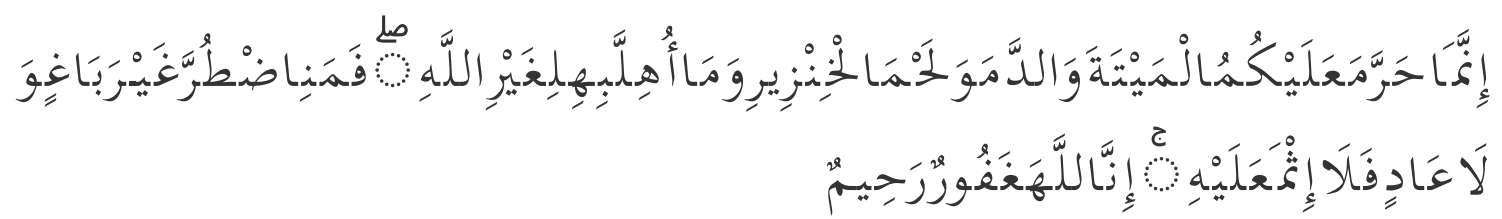

Artinya ; Sesunggubnya Allah hanya mengharamkan bagimu bangkai, darah, daging babi, dan binatang yang (ketika disembelih) disebut (nama) selain Allah. tetapi Barangsiapa dalam Keadaan terpaksa (memakannya) sedang Dia tidak menginginkannya dan tidak (pula) melampaui batas, Maka tidak ada dosa baginya. Sesunggubnya Allah Maha Pengampun lagi Maha Penyayang.

Dalam kontek nas, haram memakan bangkai seperti ayat diatas, akan tetapi dalam kontek maslahah, di bolehkan memakan barang bangkai disebabkan ada illat berupa keadaan yang memaksa bagi orang, untuk memakan brang bangkai tersebut. Akan tetapi kebolehan yang diberikan oleh kaidah ini, sesuai dengan kadar kemafsadatannya, tidak melebihi dari batas standart yang telah ditentukan oleh nash.

Dalam ayat lain disebutkan surat al-An'am 119;

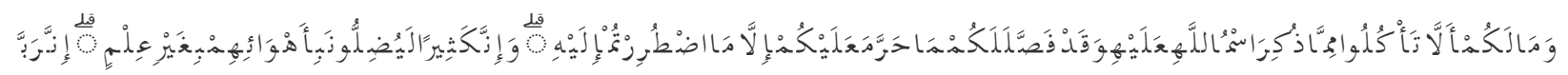

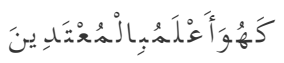

\footnotetext{
${ }^{16}$ A Djazuli, Kaidah-Kaidah Fikih (Kaidah-Kaidah Hukum Islam dalam Menyelesaikan Masalah-Masalah yang Praktis), Jakarta: Kencana, 2011.
} 
mengapa kamu tidak mau memakan (binatang-binatang yang halal) yang disebut nama Allah ketika menyembelihnya, Padahal Sesungguhnya Allah telah menjelaskan kepada kamu apa yang diharamkan-Nya atasmu, kecuali apa yang terpaksa kamu memakannya. dan Sesunggubnya kebanyakan (dari manusia) benar benar bendak menyesatkan (orang lain) dengan hawa nafsu mereka tanpa pengetahuan. Sesunggubnya Tuhanmu, Dia-lah yang lebih mengetahui orang-orang yang melampaui batas.

Dari landasan ayat diatas di peroleh pemahaman bahwa sesuatu yang dhorurot, maka barang/perbuatan tersebut boleh dilakukan. Syaikh Muhammad bin Shalih Al-Utsaimin rahimahullah ketika mengomentari kaidah ini, beliau mengutip dalil yang menjadi dasar kaidah ini atau dasar bolehnya melakukan hal yang terlarang dalam keadaan darurat. ${ }^{17}$ Syaikh Abdullah bin Abdurrahman Al-Bassam rahimahullah mendefinisikan makna darurat sebagai sesuatu yang menyebabkan bolehnya melakukan suatu perkara yang dilarang. ${ }^{18}$ Akan tetepai ada beberapa Syarat-syarat dari kaedah ini dilakukan agar supaya dalam melaksanakan perbuatan tersebut tidak sembarangan dan adapun batasan/syarat-syarat itu ;

1. Perbuatan /barang haram dapat dipastikan dapat menghilangkan bahaya (dhoror).

2. Upaya lain yang halal Tidak ada jalan lain kecuali perbuatan/barang tersebut yang ada.

3. Keharaman barang/perbuatan yang lakukan lebih ringan dari bahaya yang akan menimpanya.

4. Berkeyakinan bahwa dhoror (bahaya), bukan hanya sekedar (dhonni) atau sangkaan akan tetapi betul-betul akan terjadi dhoror tersebut. Apalagi diperkuat dengan hasil analsisis/penelitian yang mendalam.

5. Kondisi darurat tersebut benar-benar memaksa untuk melakukan hal tersebut karena dikhawatirkan kehilangan nyawa atau anggota badannya.

6. Keharaman yang ia lakukan tersebut tidaklah menzalimi orang lain.

7. Tidak melakukannya dengan melewati batas. Cukup sekadar yang ia perlukan untuk menghilangkan mudarat.

Pengecualian dari kaidah ini, diantaranya ini adalah apabila seseorang dipaksa untuk kafir, membunuh orang lain, atau berzina, maka ia tidak boleh melakukannya.

\footnotetext{
${ }^{17}$ Al-Utsaimin, Muhammad bin Shalih. 1430 H. Syarh Manzhumah Ushul al-Figh wa Qawaidih, Dar Ibn al-Jauzi: Unaizah - KSA. .

${ }_{18}$ Al-Bassam, Abdullah bin Abdurrahman. 1416 H. Taudhih al-Ahkam fi Bulugh al-Maram, Dar al-Qiblah li atsTsaqafah al-Islamiyah: Jeddah - KSA. Cetakan ke-1.Jilid ke-1. Halaman 80
} 


\section{Beberapa contoh Penerapan kaidah ini sebagai berikut:}

1. Seorang dokter boleh menyingkap sebagian aurat pasiennya jika memang pengobatan tidak bisa dilakukan kecuali dengannya.

2. Seseorang boleh memakan bangkai atau daging babi jika ia tidak menemukan makanan untuk dimakan di saat kelaparan yang teramat sangat.

3. Bolehnya seseorang makan harta orang lain dalam keadaan terpaksa.

4. Bolehnya berobat dengan sesuatu yang najis jika tidak terdapat obat selainnya.

5. Bolehnya membunuh perampok jika hanya dengan cara itu ia bisa menyelamatkan diri, keluarga, dan hartanya.

6. Bolehnya seseorang mengambil harta milik orang yang berhutang darinya tanpa izin jika ia selalu menunda pembayaran sedangkan ia dalam keadaan mampu.

\section{B. Macam-Macam Keadaan Memaksa ;}

1. Keadaan Memaksa Absolut ${ }^{19}$. Keadaan memaksa absolut adalah suatu keadaan dimana pihak pertama (satu) sama sekali tidak dapat memenuhi perutangannya kepada pihak kedua, sepertiBencana alam (gempa bumi, tanah longsor, dan banjir), kebakaran, Perang, huru-hara, pemberontakan, pemogokan, dan epidemi (wabah penyakit), Tindakan pemerintah di bidang moneter yang langsung mengakibatkan kerugian luar biasa. Contohnya, si A ingin membayar utangnya pada si B. Namun tiba-tiba pada saat si A ingin melakukan pembayaran utang, terjadi gempa bumi. Maka si A sama sekali tidak dapat membayar utangnya pada si B, karena barangnya hilang.

2. Keadaan Memaksa yang Relatif. Keadaan memaksa yang relatif adalah suatu keadaan yang menyebabkan pihak satu mungkin untuk melaksanakan kewajibannya. Contohnya, A telah meminjam, kredit usaha tani dari KUD, dengan janji akan dibayar pada musim panen. Tetapi sebelum panen, padinya diserang oleh ulat. Dengan demikian, pada saat itu ia tidak mampu membayar kredit usaha taninya kepada KUD, tetapi ia akan membayar pada musim panen mendatang.Adanya keadaan memaksa yang relatif ini, sangat tergantung dari pada isi, maksud, dan tujuan dari hubungan hukum yang bersangkutan dari kedua belah pihak.

\section{Konsepsalam dalam tinjauan fiqih.}

Ulama' kontemporer berpendapat bahwa jual beli salam sah berdasarkan Qiyas. menurut mayoritas ulama,salam termasuk salah satu aplikasi jual beli as-salam, jadi

\footnotetext{
\begin{tabular}{l|l}
${ }^{19}$ Rahmad SS Soemadipradja, Penjelasan Hukum tentang Kead \\
\hline 62 & Profit : Jurnal Kajian Ekonomi dan Perbankan
\end{tabular}
} 
berlaku syarat-syarat jual beli. Menurut ulama Hanafiah, Malikiyah dan Hanbalilah, jual beli pesanan, barangnya harus diserahkan kemudian, sesuai dengan waktu yang disepakati bersama.Namun ulama Syafi'iyah berpendapat, barangnya dapat diserahkan pada saat akad terjadi. Apabila syarat dan rukun telah terpenuhi, maka jual beli pesanan itu dinyatakan sah dan masing-masing pihak terikat dengan perjanjian dan ketentuan disepakati. $^{20}$

Persoalan salam yang menjadi masalah yang rumit yaitu apabila ketika penyerahan barang pada saat sudah jatuh tempo, barang tidak sesuai dengan spesifikasi? Tempat dan lokasi membutuhkan biaya yang besar untuk pengirimannya? Atau apabila terjadi barang tidak ada saat jauh tempo disebabkan oleh forcer majure ?siapakah yang mengganti barang tersebut dan biaya pengirimannya?

Salam atau Bai' istis'na' termasuk dalam kategori natural certainly contracts, yaitu kontrak/akad dalam bisnis yang memberikan kepastian pembayaran, baik dari segi jumlah ( amount) maupun waktu ( timing)nya. Cash flow nya bisa diprediksi dengan relatif pasti, karena sudah disepakati oleh kedua belah pihak yang bertransaksi di awal akad. Kontrak ini secara, sunnatullah' ( by their nature) menawarkan return yang tetap dan pasti. Jadi sifatnya fixed and predetermined. Obyek pertukarannya baikjumlahnya ( quantity), mutunya ( quality), harganya ( price ), dan waktu penyerahannya ( time of delivery ). ${ }^{21}$

Dalam persoalan ini fuqaha sepakat menyatakan, bahwa pihak produsen wajibmenyerahkan barang itu pada waktu dan tempat yang telah disepakati bersama. Meskipun barang yang diterima terdapat cacatatau tidak sesuai dengan sifat-sifat, ciri-ciri, kualitas ataukuantitas barang yang dipesan itu, maka pihak pemesan (konsumen) bolehmenyatakan, apakah ia menerima atau tidak, sekalipun dalam jual beli pesanan initidak ada hak khiyar. Pihak konsumen boleh meminta ganti rugi, meminta digantisesuai pesanan yang dicantumkan dalam perjanjian (terutamapesanan dalam jumlah/partai besar).Apalagi dalam praktik pesanan model saat ini di dunia modern yang semakin berkembang, seperti hubungan negara (import dan eksport) yang membutuhkan sistem, manajemen serta operasional yang akuntable dan profesional. Oleh sebab itu,

\footnotetext{
${ }^{20}$ Ibnu Rusyd, Bidayatul Mujtahid wanihaytul Muqtasid, 20

${ }^{21}$ Adiwarman A. Karim, Bank Islam; Analisis Fiqih dan Keuangan, (Jakarta: PT Raja Grafindo Persada, 2006), 51.
} 
model pesanan harus sesuai dengan nilai-nilai syariat Islam, tidak merugikan orang lain serta memperkecil perselisihan diantara sesamanya. ${ }^{22}$

\section{Tinjauan Maqosidus Syariah Secara Umum}

Syariat adalahajaran dan merupakan pedoman hidup bagi seluruh umat manusia.Dalam ruang lingkup ushul fiqh ada tujuan yang ingin dicapai oleh syariat yang disebut dengan maqashid as-syari'ah yaitu maksud dan tujuan diturunkannya syariat Islam. $^{23}$

Maqashid Syariah secara istilah adalah tujuan-tujuan syariat Islam yang terkandung dalam setiap aturannya. Imam Asy-Syathibi mengungkapkan tentang syari'ah dan fungsinya bagi manusia seperti ungkapannya dalam kitab al-Muwwafaqat: ${ }^{24}$

$$
\text { هذه الثريعة .... وضعت لتحقيق مقاصد الثار ع في قيام مصالحهم في الدين و الدنيا معا }
$$

Sesunggubnya syariat itu ditetapkan bertujuan untuk tegaknya (mewujudkan) kemashlahatan manusia di dunia dan Akbirat".

Pada bagian lainnya beliau menyebutkan:

$$
\text { الاحكام مشرو عة لمصالح العباد }
$$

\section{Hukum-bukum disyariatkan untuk kemashlahatan hamba.}

Al-Syatibi tidak mendefinisikan Maqashid Syariah yaitu mashlahah atau kebaikan dan kesejahteraan umat manusia baik di dunia maupun diakhirat.Oleh karena itu Asy-Syatibi meletakkan posisi maslahat sebagai 'illat hukum atau alasan pensyariatan hukum Islam, berbeda dengan ahli ushul fiqih lainnya An-Nabhani misalnya beliau dengan hati-hati menekankan berulang-ulang, bahwa maslahat itu bukanlah illat atau motif (al-bacits) penetapan syariat, melainkan hikmah, hasil (natijah), tujuan (ghayah), atau akibat ('aqibah) dari penerapan syariat. ${ }^{25}$

Beberapa Ulama mendefinisikan Maqashid Syariah sebagai berikut: ${ }^{26}$

$$
\text { المقاصد العام للثارع في تشريعة الاحكام هو مصالح الناس بكفلة ضرورياتهم وتوقير حاجياتهم وتحسناتهم }
$$

Maqashid Syariah secara Umum adalah: kemaslahatan bagi Manusia dengan memelihara kebutuhan dharuriat mereka dan menyempurnakan kebutuban Hajiyat dan Tabsiniat mereka.

22Ibid

23ibid

${ }^{24}$ Ika Yunia Fauzia, Abdul Kadir Riyadi, Prinsip Dasar Ekonomi Islam, Perspektif Maqashid al-Syariah, Kencana, 2014, Jakarta

${ }^{25}$ Forum Karya Ilmiah, Kilas Balik Teoritis Fiqih Islam, Kediri: Purna Aliyah, 2004.

${ }^{26}$ Ibid, 
Dari pendapat tersebut dapat disimpulkan bahwa konsep Maqashid Syari'ah adalah untuk mengetahui hikmah (nilai-nilai inti dari ajaran islam) yang terkandung didalam syariat/ajaran islam yang bersumber dari Al-Qur'an dan Hadits), secara umum syariat bertujuan untuk kemashlahatan dan kesejahteraan umat manusia baik di duniamaupun di akhirat.Sedangkan cara untuk tercapai kemaslahatan tersebut manusia harus memenuhi nilainilai dari kebutuhan dasar yang disebut Dharuriat (Primer), kebutuhan tambahan (skunder) Hajiyat, dan kebutuhan sebagai pelengkap yang disebut tahsiniat (tersier).

Abu Ishaq al-Shatibi merumuskan lima tujuan hukum Islam, yakni ${ }^{27}: \mathrm{Hifd}_{\mathrm{f}}$ Ad-Din (Memelihara Agama),2)Hifdz An-Nafs (Memelihara Jiwa), 3.Hifdz Al'Aql (Memelihara Akal),4.Hifdz An-Nasb (Memelihara Keturunan), 5.Hifdz Al-Maal (Memelihara Harta). Untuk lebih memahami global tentang maqosidus syariah diperlukan pemahaman juga tentang al-maslahah. Jalaluddin Abdurrahman menjelaskan bahwa maslahat secara umum adalah apa- apa yang bermanfaat, berguna bagi manusia baik yang dapat mendatangkan kebaikan maupun yang bersifat untuk menghilangkan kesulitan dan kesusahan. ${ }^{28}$ Secara substansi esensi dari maslahat adalah terciptanya kebaikan, kemanfaatan, berguna dalam kehidupan manusia serta terhindar dari hal-hal yang bisa mendatangkan mudhorot/kerusakan.

Dilihat dari segi pembagian maslahat ini, dapat dibedakan kepada dua macam, yaitu dilihat dari segi tingkatannya dan eksistensinya. ${ }^{29}$

1. Maslahat dari segi tingkatannya dibedakan 3 macam, yaitu :a. Maslahat Daruriyat ( ( ). maslahat ini menjadi dasar tegaknya kehidupan asasi manusia yang berkaitan dengan agama, nyawa maupunrusaknya tatanan kehidupan di dunia(Ruang lingkup maslahat daruriyat ada 5 macam, yaitu berkaitan dengan pemeliharaan agama, jiwa, akal, keturunan dan harta). b. Maslahah Hajiyat المصالح الحاجية)). Maslahah ini dibutuhkan manusia untuk menghilangkan kesulitan dan kesusahan yang dihadapi.c.Maslahah Tahsiniyah (المصالح التحسنية )disebut juga maslahat takmiliyah. maslahat ini sifatnya untuk memelihara kebagusan dan kebaikan budi pekerti serta keindahan saja. Maslahat tahnisiyah bersifat sebagai pelengkap yaitu berupa keleluasaan untuk melengkapi kemaslahatan sebelumnya.

\footnotetext{
${ }^{27} \mathrm{Ibid}$,

${ }^{28}$ Muhammad AbuZahro, Ushul Fiqh, Jakarta: Pustaka Firdaus, cet 9, 2005

${ }^{29} \mathrm{lbid}$, 
2. Maslahat ditinjau dari segi eksistensinya/wujud, para ulama ushul sebagaimana dijelaskan oleh Abdul Karim Zaidan, membaginya kedalam 3macam :a. Maslahah Mu'tabarah ( kemaslahatan yang terdapat nash secara tegas menjelaskan dan mengakui keberadaannya.Seperti ; qisash bagi pembunuh,dll. b.Maslahah Mulgha( المصالح الملغاة ). maslahat yang berlawanan dengan ketentuan nash. Artinya jenis maslahat ini tertolak karena ada dalil yang menunjukkan bahwa, maslahat ini bertentangan dengan dalil yang sharih (jelas).c. Maslahat Mursalah (المصالح المرسلة) maslahat ini secara eksplisit tidak ada nash/dalil yang mengakui maupun yang menolaknya, tetapi keberadaannya selalu sejalan dengan tujuan syariat.

Ada beberapa pembaharuan yang dilakukan oleh Ibnu Ashur di bidang maqashid syariah di antaranya ialah semua hukum baik yang bersifat muamalah (transaksional) atau ibadah (ritual), semuanya mempunyai illat (sebab). Dalam mengoperasionalkan teori maqashid ia berpegang pada tiga prinsip dasar yaitu 1. maqam khitab al syar'iy (situasi dan kondisi khitab syar'iy), 2. al tamyiz baina al wasilah wa al maqshud (membedakan antara prasarana dan tujuan), 3.istiqra' (induksi).menarik kesimpulan daam fonema hukum-hukumyang bersifat parsial ke hukum global.

Dalam beberapaperkembangannya tentangkemudian muncul beberapa pertanyaan yang terkait dengan isu syari'at dan kemaslahatan, bagaimana apabila pertimbangan hukum atas dasar kemaslahatan tersebut bertentangan dengan teks kedua sumber hukum, baik Al-Qur'an maupun hadits dan dengan Ijma' ulama (consensus).apakah manusia (masyarakat) mengikuti agama atau agama mengikuti manusia (Masyarakat)? Ada pandangan dari Dr. Musthafa Syalabi dalam bukunya "Ta'lil al-Ahkam", mengatakan: ${ }^{30}$

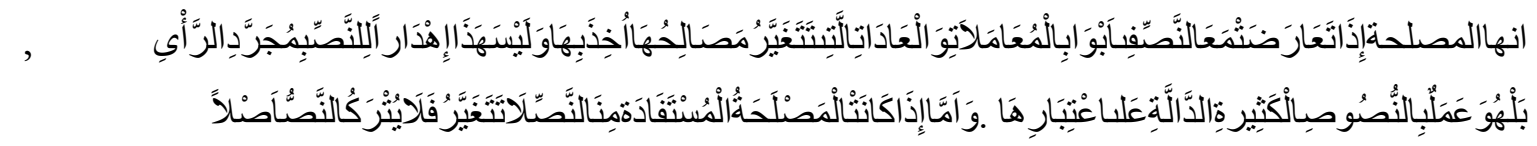

"Apabila kemaslahatan bertentangan dengan "nash”(teks), dalam bidang mu'amalat danadatkebiasaan(tradisi)yang kemaslahatannya telah berubah, maka kemaslahatanlah yang harus dipertimbangkan, dan hal ini tidaklah dapat dikatakan sebagai menentang "nash" melalui semata-mata pendapat nalar/akal. Sebaliknya ia justeru mengaplikasikan "nash-nash” yang sangat banyak yang

${ }^{30}$ Dr. Musthafa Syalabi, “Ta'lil al-Ahkam,Beirut dar al- Nahdhah al-Arabiyah, 1981 
menunjukkan keharusan menjaga kemaslahatan tersebut. Akan tetapi apabila kemaslahatan dalam "nash" tidak berubah, maka nash sama sekali tidak boleh diabaikan".

Syalabi selanjutnya mengatakan:

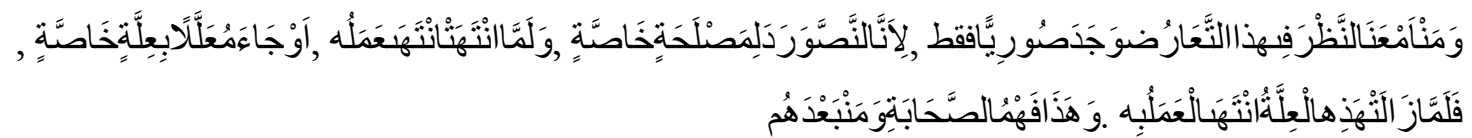

"Siapapun yang merenungkan secara mendalam tentang adanya kontradiksi tersebut, hal itu sebenarnya hanyalah dalam bentuk labiriyahnya saja. Hal ini karena nash sesunggubnya diturunkan Tuhan (dibuat) dalam rangka menegakekan kemaslahatan tertentu. Manakala kemasalabatan tersebut telah hilang, maka ia tidak relevan lagi untuk diimplementasikan. Demikian pula apabila nash disertai dengan "illat" (logika kausalitas) nya. Manakala illat tersebut hilang, maka hukum tersebut juga selesai.Ini adalah pemahaman para sababat dan generasi sesudahnya”.

Para sahabat seperti Umar bin Khattab salah satu keputusannya berdasarkan prinsip kemaslahatan ini. pembatalan hukuman potong tangan ketika masyarakat menghadapi situasi krisis pangan. Banyak rakyat yang kelaparan.Ia juga tidak membagikan tanah rampasan perang kepada para tentera, tetapi menyerahkannya kepada Negara untuk kepentingan yang lebih luas. Padahal Nabi membagikannya kepada para prajurit. Perbedaaan Keputusan Umar dengan keputusan Nabi , Apakah menentang Nabi ? Jawabannya tentu tidak. Tindakan Umar justeru menegakkan maksud, ghayah dan eksistensi dalam visi al-Qur'an, sebagaimana dilakukan oleh Nabi. Pemahaman umar dengan Nabi bahwa hukum yang diputuskan pada zaman Nabi relevan dengan kemaslahatan sosialnya (tujuan dari Al-Qur'an). Perbedaan keputusan hukum pada zaman Nabi dan Umar akibat perkembangan social yang berubah, dan keputusan Nabi tersebut tidak lagi sesuai dengan kemaslahatan sosialnya.

Perbedaan perkembangan sosial yang beragam apalagi islam menyebar ke saentero dunia para ulama' fiqh para ulama pendiri mazhab maupun para pengikutnya, tampak jelas bahwa pandangan mereka hampir selalu berbeda-beda dan beragam, meskipun mendasarkan diri pada sumber hukum yang sama. Beberapa contoh kasus, misalnya wali nikah perempuan, saksi nikah, usia dewasa, talak tiga, begitu juga dalam bidang muamalah, jinayah dan sebagainya. Keputusan mereka sangat dipengaruhi oleh ruang, waktu, dan keadaan sosial masyarakat yang berbeda dan dinamis. Pandangan-pandangan fiqh Islam tidak lain kecuali merupakan refleksi dari perkembangan kehidupan sosial dalam masyarakat Islam. Pandangan-pandangan tersebut akan berubah, berkembang dan berganti-ganti sejalan dengan situasi zaman dan konteks sosialnya masing-masing. 
Dari pandangan mereka kemudian melahirkan kaidah hukum ; "La Yunkaru Taghayyur al-Ahkam bi Taghayyur al-Azminah wa al-Amkinah wa al-Ahwal" (Perubahan bukum terjadi karena perubahan zaman, lokalitas dan situasi sosial). ${ }^{31}$

Ibnu al-Qayyim menyampaikan kaedah ini secara lebih lengkap.Ia mengatakan "Perubahan fatwa dan perbedaannya berdasarkan perubahan zaman, tempat, kondisi social, motivasi dan adat-istiadat (tradisi)”.

Perubahan hukum karena perubahan ruang, waktu dan perkembangan social, perumusan hukum juga meniscayakan prinsip-prinsip yang lebih mendasar yang disbeut prinsip-prinsip kemanusiaan Universal, Para ulama menyebutnya sebagai "Al-Kulliyyat alKhams" (lima prinsip universal) atau "al-Dharuriyyat al-Khams" (lima prinsip niscaya) dan "Maqashid al-Syari'ah" (tujuan syari'at/agama). Imam al-Ghazali mengulas dalam kitab "AlMustashfa Min 'Ilm al-Ushul”, dan diuraikan lebih luas oleh Imam Al-Syathibi dalam bukunya “Al-Muwafaqat fi Ushul a-Syari’ah”.Yakni : Hifzh al-Din (perlindungan terhadap agama/keyakinan, Hifzh al-Nafs (perlindungan terhadap hak hidup (life), Hifzh al-'Aql (perlindungan terhadap hak berpikir dan mengekspresikannya, Hifzh al-Nasl (perlindungan terhadap hak-hak reproduksi dan Hifzh al-Mal (perlindungan terhadap hak-hak milik/property.

Pada era sesudahnya, sejalan dengan realitas baru yang terus berkembang, ada beberapa tokoh pemikir muslim menambahkan dua prinsip lagi. Yaitu "Hifzh al-'Irdh" (perlindungan atas kehormatan) dan "Hifzh al-Bi-ah"perlindungan terhadap lingkungan alam (konservasi).Lima (atau tujuh) prinsip di atas dinyatakan oleh Imam Abu Ishaq al-Syathibi sebagai konsensus agama-agama (Ittifaqal-Milal). Sementara Dr. Abdullah Darraz mengatakan : "Lima prinsip di atas merupakan dasar-dasar pembangunan/kemajuan masyarakat dalam semua agama. Tanpa lima dasar ini kehidupan bersama manusia tidak akan stabil dan kebahagiaan di akbirat tak akan dicapai”.

Aplikasi dari pemaparan dan pandangan ulama' tentang maslahah, apabila ditarik keranah muamalat dalam hal ini pada akad salam ada beberapa persoalan-persoalan (perselisishan diantaraakid dan makkud) seperti perselisihan dalam model, bentuk, kualitas, kuantitas, waktu dan tempat untuk pengiriman pada akad tersebut. Masalah tersebut akan berdampak signifikan ketika dikaitkan dengan wilayah (zona) bagi si penjual yang hanya

\footnotetext{
${ }^{31}$ Forum Karya Ilmiah, Kilas Balik Teoritis Fiqih Islam, Kediri: Purna Aliyah, 2004.
} 
membutuhkan biaya/ongkos pengiriman lebih besar dari sebelumnya. Hal ini juga ketika dikaitkan semisal diluar wilayah/batas negara yang memerlukan tambahan biaya yang cukup mahal, atau juga apabila terjadi force majeure (sesuatu yang tidak dikehendaki) seperti bencana alam dan hal-hal lain.

Abu Ishaq al-Shatibi merumuskan lima tujuan hukum Islam seperti yang telah disebutkan diatas. Salah satu kriteria dari akad salam dalam maqosid adalah untuk menjaga harta (hifdulma), pengembangandari kaidah ini hifdulirdh (untuk menjaga kehormatan). Dalam penerapan salam dapat diambil suatu pemahaman bahwa menjaga harta (kehormatan) merupakan kewajiban individu dalam transaksi yang dilakukan oleh pihak penjual kepada pembeli. Hak milik harta yang dimiliki oleh si penjual kepada si pembeli status hartanya berubah dalam hal kepemilikannya.Berubahnya status kepemilikan tersebut secara otomatis berubah juga semua illat (ketentuan-ketentuan hukum) dalam barang tersebut, menjadi milik si pembeli dalam hal ini pihak kedua.

Akan tetepai keika terjadi sesuatu diluar proses yang telah diakadkan misal ada cacat dalam barang, barang tidak sesuai dengan spesifikasi, atau apabila terjadi force majeure maka dalam tinjuan maqosidus syariah adalah barang di tafsil (di rinci) mengapa terjadi barang yang tidak sesuai dengan spesifikasi yang telah diperjanjikan. Untuk megukur keabsahan penerimaan barang maka ada proses hukum yang menjadi illat dari proses tersebut.

Ada beberapa proses yang dilakukan untuk mentafsil masalah tersebut, seperti yang dilakukan oleh Ibnu Ashur di bidang maqashid syariah di antaranya ialah semua hukum baik yang bersifat muamalah (transaksional) atau ibadah (ritual), semuanya mempunyai illat (sebab). Dalam mengoperasionalkan teori maqashid ia berpegang pada tiga prinsip dasar yaitu 1. maqam khitab al syar'iy (situasi dan kondisi khitab syar'iy), 2. al tamyiz baina al wasilah wa al maqshud (membedakan antara prasarana dan tujuan), 3.istiqra' (induksi)menarik kesimpulan dalam fenomena hukum-hukumyang bersifat parsial ke hukum global.

\begin{tabular}{|c|c|c|c|c|c|}
\hline المال & النسل & العقل & النفس & الدن & INDIKATOR \\
\hline 5 & 4 & 3 & 2 & 1 & الضرورى \\
\hline 10 & 9 & 8 & 7 & 6 & حا جيات \\
\hline 15 & 14 & 13 & 12 & 11 & تحسنيات \\
\hline
\end{tabular}


Dari gambar tersebut dapat diambil penjelasan bahwa apabila akad salam pada tersebut berada di posisi dhoruri, semisal akan merusak pada tatanan sosial, maka dipastikan hal tersebut boleh dilakukan untuk menjaga tatanan sosial, meskipun pada posisi di hifdul mall. Begitu juga sebaliknya.

Ketentuan hukum ini akan berubah secara totalitas ketika berkaitan dengan force majeure. Bahwa semua ketentuan hukum (transaksi/kontrak, dan lain sabagainya) apabila terjadi kemudharatan secara global, akan berdampak implikasi hukum yang menyeluruh dari semua segi. Semisal ; apabila terjadi bencana alam, banjir dan lain lain.

Dari beberapa paparan diatas bisa ditarik kesimpulan bahwa maqasid shariah adalah tujuan-tujuan akhir yang harus terealisasi dengan diaplikasikannya syariat. Maqasid al shariah bisa berupa maqasid shariah al'ammah, yang meliputi keseluruhan aspek syariat dan maqasid shariah al khasah yang dikhususkan pada satu bab dari bab-bab syariat yang ada, seperti maqasid al shariah pada bidang ekonomi, hukum keluarga dan lain-lain, atau maqasid shariah al juz'iyyah yang meliputi setiap hukum shara' seperti kewajiban shalat, diharamkannya zina, dan sebagainya. ${ }^{32}$

\section{PENUTUP}

Force majure akan merubah ketentuan hukum secara totalitas ketika berkaitan dengan semua ketentuan hukum (transaksi/kontrak, dan lain sabagainya) yang berakibat pada kemudharatan secara global.

Disamping itu maqasid shariah merupakan tujuan akhir yang harus terealisasi dengan diaplikasikannya syariatislam. Maqasid al shariah bisa berupa maqasid shariah al'ammah, yang meliputi keseluruhan aspek syariat dan maqasid shariah al khasah yang dikhususkan pada satu bab dari bab-bab syariat yang ada, seperti maqasid al shariah pada bidang ekonomi, hukum keluarga dan lain-lain, atau maqasid shariah al juz’iyyah.

Pandangan diatas pada gilirannya membawa serta konsekuensi dan keharusan bahwa kita semua dituntut berjuang dan bekerja secara terus menerus dan tanpa lelah, untuk menghormati kesucian martabat orang lain, menegakkan keadilan, menaklukkan kecenderungan egoisme dan arogansi yang ada dalam diri kita sambil meletakkan orang lain di dalam hati kita, dan memandang tiap manusia tanpa kecuali, sebagai ciptaan Tuhan yang setara dan mulia.

\footnotetext{
${ }^{32}$ H Iamam Mawardi, Fiqh Minoritas, Yogyakarta, Lkis, 2010 
Semua tindakan dan sikap yang baik di atas betapapun beratnya, sesungguhnya tidaklah akan sia-sia dan tidak akan hilang ditelan embusan angin kemarau, melainkan akan selalu berguna bukan hanya bagi dirinya sendiri tetapi juga bagi orang lain dan alam semesta. Tuhan tak pernah mengabaikan kerja-kerja manusia sekecil apapun. 


\section{DAFTAR PUSTAKA}

Ismail Nawawi, Fiqh Muamalah Klasik dan Kontemporer,Viva Pres Sidoarjo,2011

Prof DR Sutan Remy Sjahdeini, SH, Perbankan Syariah, Produk-Produk dan Aspek-Aspek Hukumnya, Kencana, Jakarta, 2015), 251

Veithzal Rivai, IslamicFinancialManagement, Rajawali Pers, 2008, Jakarta, Rajagrafindo Persada

Daryl John Rasuh, Kajian Hukum Keadaan Memaksa, (Force Majeure) menurut Pasal 1244 dan Pasal 1245 KUHPerdata, Jurnal Lex Privatum Vol 4 No 2 Februari 2016,

R.Subekti, Hukum Perjanjian, Jakarta, PT.Intermassa, 1979,55

A Djazuli, Kaidah-Kaidah Fikih (Kaidah-Kaidah Hukum Islam dalam Menyelesaikan Masalah-Masalah yang Praktis), Jakarta: Kencana, 2011.

Al-Utsaimin, Muhammad bin Shalih. 1430 H. Syarh Manæ̧humah Ushul al-Fiqh wa Qawaidih, Dar Ibn al-Jauzi: Unaizah - KSA. .

Al-Bassam, Abdullah bin Abdurrahman. 1416 H. Taudhih al-Ahkam fi Bulugh al-Maram, Dar al-Qiblah li ats-Tsaqafah al-Islamiyah: Jeddah - KSA. Cetakan ke-1.Jilid ke-1.

Rahmad SS Soemadipradja, Penjelasan Hukum tentang Keadaan Memaksa, Gramedia, Jakarata, 2010

Ibnu Rusyd, Bidayatul Mujtahid wanihaytul Muqtasid,

Adiwarman A. Karim, Bank Islam; Analisis Fiqih dan Kenangan, (Jakarta: PT Raja Grafindo Persada, 2006),

Ika Yunia Fauzia, Abdul Kadir Riyadi, Prinsip Dasar Ekonomi Islam, Perspektif Maqashid al-Syariah, Kencana, 2014, Jakarta

Forum Karya Ilmiah, Kilas Balik Teoritis Fiqih Islam, Kediri: Purna Aliyah, 2004.

Muhammad Abu Zahro, Ushul Fiqh, Jakarta: Pustaka Firdaus, cet 9, 2005

Dr. Musthafa Syalabi, "Ta'lil al-Abkam,Beirut dar al- Nahdhah al-Arabiyah, 1981

H Imam Mawardi, Fiqh Minoritas, Yogyakarta, Lkis, 2010 